\title{
Which is the role of the numerical flexibility on the Family Firm's learning-by-exporting capability?
}

\author{
Joaquín Monreal-Pérez \\ University of Murcia (Spain) and Kiel Institute for the World Economy (Germany)
}

Email adress:

jomonreal@um.es (J. Monreal-Pérez)

\section{To cite this article:}

Joaquín Monreal-Pérez. Which is the Role of the Numerical Flexibility on the Family Firm's Learning-By-Exporting Capability? International Journal of Business and Economics Research. Vol. 1, No. 1, 2012, pp. 1-11. doi: 10.11648/j.ijber.20120101.11

\begin{abstract}
Family firms are said to be of great flexibility [1], what may enhance their export activity and therefore make them benefit from one of the main export advantages: the learning-by-exporting effect on various outputs, among which this work focuses on innovation. Data from the period 2001-2010 from over 2,200 Family Firms (out of a sample of 4,629) are analyzed to test if being numerical more flexible (through the hiring of temporary workers) implies that the learning-by-exporting effect on the innovative activity is enhanced through such practice. Results show that being more flexible doesn't make the firm to export more. Moreover, the firm numerical flexibility exerts no clear effect on innovation. What is non-contradictory is the learning-by-exporting effect on innovation. Exporting is exogenous to innovation, what suggest the absence of a self-selection effect between these variables. Finally, the firm numerical flexibility doesn't moderate, in any sense such effect.
\end{abstract}

Keywords: Learning-By-Exporting, Family Firms, Numerical Flexibility

\section{Introduction}

Among the advantages from exporting, learning from the export markets to improve the firm performance is of great importance [the so-called learning-by-exporting effect; 2]. Become more innovative makes the firm more competitive, both domestically and internationally [3]. This is because of two reasons: first, because innovation allows the firm differentiate itself from other competitors $[4,5,6]$; and second, because innovation is inimitable, since it represents an original combination of the organizational resources and is developed over the lifetime of the firm. Imitation is difficult because the firm's competitors may not possess the necessary resources to fully exploit this capacity [7].

Additionally, in recent years, the economic crisis has driven firms to sell their goods and services abroad. Because of the decrease in domestic demand, firms have found that their products are more difficult to sell to their local markets. All these features strengthen the current importance of exporting for the firm performance improving and, even, for its survival.

In this context, identifying which are the factors that enable the family firm (FF, from now on) to increase its export and innovative activity is of great opportunity. The EU, in various reports has highly recommended the European labor markets to be more flexible [eg, see 8]. This feature, since favors a quicker adaptation to different market conditions, may help the firm intensifying (directly) its internationalization and, additionally, directly and indirectly (via the learning-by-exporting effect) its innovative capacity.

Among all kind of firms, why we focus on the family ones? Mainly because of their great importance, especially in Spain: $85 \%$ of the Spanish firms were familiar, while their contribution of the Spanish GDP was of $70 \%$. Moreover, 6 out of every 10 Euros exported by the Spanish firms came from FFs [9]. When we compare these data with those from the EU, the special relevance of the FF in Spain stands out: in the EU, $60 \%$ of the firms are of family nature, while they contribute to the GDP with a $65 \%$ (in the US, FFs provide only the half of the total GDP). When studying the FF internationalization, there is no sound consensus among empirical studies on whether these firms' nature restrains or facilitates their export activity. We can exhibit recent opposite evidence here: reference [1] find that the small size and the flexibility of the management teams in family firms allow them to react quickly to new international opportunities. Meanwhile, [10] conclude that FFs exhibit lower levels of internationalization than non-FFs due to their concern with preserving the family control of the business. This special behavior of the FF when addressing its internatio- 
nalization leads us to wonder whether there is any difference when analyzing the learning-by-exporting effect on FFs.

If carrying out exports exerted a learning effect 1 on innovation, the circle would be completed and this fact would enhance the advantages of exporting. In this sense, a number of studies argue that there is a learning-by-exporting effect on innovation: because of the highly competitive pressure of international markets, which forces firms to constantly update their products and adapt to new market conditions [11, 12], and due to the fact that the knowledge acquired in the export market allows a firm to register more patents and develop more innovative products [13]. This evidence makes us wonder if there is a learning-by-exporting effect on innovation happening when considering the Spanish manufacturing firm.

In this context, a study on the Spanish FFs export activity can help extending the existing knowledge in this stream of research. Although Spain is among the world's top ten economies, its international presence through exports is relatively weak 2 . However, some recent studies have shown that Spain's low level of exports is due to a lack of technological innovation whereas other scholars have attributed Spain's export habits to the country's low level of productivity in comparison with those of other EU countries, such as France, Germany or the Netherlands [15-17]. Thus, since the strategic importance of being innovative to improve the international competitiveness, and since exporting is crucial for the Spanish firm (especially nowadays, given the currently low domestic demand), exploring the determinants of both activities can provide policy makers with effective tools to help improve the performance of the Spanish firm.

In short, taking into account the benefits of going international, and specifically, the ability of such activity in transferring knowledge from the export markets to the firm (the learning-by-exporting effect), and the idiosyncratic nature of family firms when facing its internationalization, this paper aims to shed light on how this learning capability works on family firms. Such study is carried out on the Spanish family firms, given the abovementioned importance for these organizations of exporting and of being innovative.

On the other hand, for the empirical analysis we test for innovation by using several proxies (i.e., R\&D dummy, $\mathrm{R} \& \mathrm{D}$ expenditure and product and process innovations). In doing so, we enable a broader interpretation of each firm's innovation activities. Moreover, analyzing all of these relationships in a longitudinal study allows us to identify the effects of specific policies on the export and innovative performance of Spanish FFs. Furthermore, we consider how the numerical flexibility moderates the learn-

\footnotetext{
1 The learning-by-exporting effect refers to the fact that the firm acquires new knowledge and becomes more competitive because of its exposure to the export markets (for further information on this effect, see 2).

${ }^{2}$ Spanish firms engage in a limited number of export activities because of their size; as most of these firms are small, they prefer to sell their products in domestic markets or choose the least risky mode of entry into the international markets (i.e., exporting; 14).
}

ing-by-exporting effect on innovation. Finally, we consider the potential endogeneity concerns related to the learning-by-exporting hypothesis, especially when we study the export-innovation link [18] following an instrumental variable strategy.

This paper is structured as follows. The first section reviews the existing literature on the relationships among innovation and the internationalization of the firm, specially focusing on the learning-by-exporting effect. In the next section, it is reviewed the literature dealing with the internationalization of the family firm. Following, we provide the theoretical framework, which leads to the research hypotheses. Then, we explain the methodology by describing the model and the measurements of the variables used in this study. This section is followed by an exposition of the results. Lastly, we discuss the empirical evidence gathered and provide the final conclusions.

\section{Theoretical Framework and Hypo- theses}

As stated above, the goal of this work is to identify the determinants which favor both the export and the innovative activity of the FF. In doing so, we focus in one factor: the numerical flexibility, given by one of the most important tools used by the firm to become more numerically flexible: the proportion of temporary workers within the FF. This goal is achieved by studying the direct effect of this variable on the firm innovative activity (H3). But previously, we try to analyze the direct impact of this covariate on the firm export activity (H2).

On the other hand, the firm export activity may positively influence the firm innovative performance through the so named learning-by-exporting effect (H1). Finally, we suggest that the proportion of temporary workers within the FF exerts a positive moderating impact on the learning-by-exporting effect proposed in H1 (H4). All these relationships are described in Fig. 1.

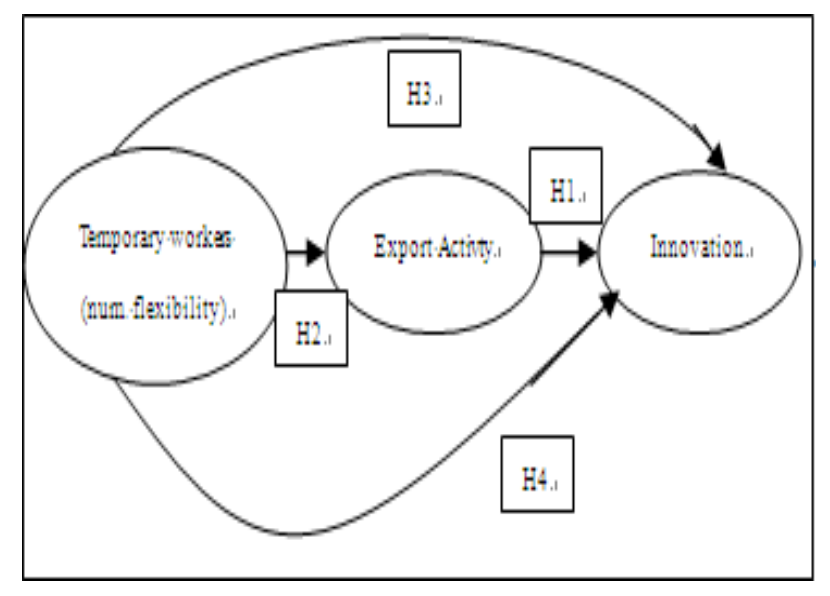

Figure 1. Theorectical framework.

Source: Own elaboration 


\subsection{Learning-by-exporting on Innovation}

The greater competitive pressure of the export markets [2] and the knowledge acquired in these markets [19-22] are the two most important arguments supported by the learning-by exporting advocates.

Regarding the first argument, several papers have shown that this highly competitive pressure of international markets forces firms to constantly update their products and adapt to new market conditions [23]. In other words, exporting firms can enhance their competences base by learning from the interactions with the international markets and therefore, developing innovative capacities [24].

In the same way, [13], when conducting a case study of Spanish firms, find that the knowledge acquired in the export market allows a firm to register more patents and develop more innovative products. These authors point out the importance of exploring the time path of the learning-by-exporting effect, as the impact on innovation may not be immediate. They find that the learning-by-exporting effect primarily affects product innovation two years after the firm begins exporting and that the number of patents registered increases with a greater lag in time. In fact, many researchers consider new knowledge to be the foundation of innovation, as they consider innovation to be an individual and collective learning process in which the innovators search for new ways to solve problems [19-22]. Innovation appears to depend on a firm's capacity to learn. Through this capacity, new knowledge is developed, distributed and used. Reference [20] affirm that internationalization doesn't only allow a firm to enrich its sources of knowledge but also enables the firm to capture ideas from a greater number of new and different markets as well as a wide range of cultural perspectives, which facilitates innovation. Both arguments suggest that exporting leads the firm to develop innovative activities, it is, there is a learning-by-exporting effect on innovation.

\subsection{Learning-by-exporting in Family Firms}

As a number of studies underline, FFs lack some resources which may restrain their internationalization. Among these resources, from a RBV perspective, [14] point out the knowledge capability as one of the main limits of the FFs' internationalization. Nevertheless, these authors argue that FFs may overcome this constraint through two means: first, by engaging in international networks, alliances, etc with foreign counterparts, and, second, following the Uppsala model that emphasizes the importance of cumulating knowledge through the experience acquired in the foreign markets [25], by increasing their internationalization. Additionally, the lack of professional managers within FFs may limit its learning capability once that they have decided start exporting. In this sense, internationalization is associated with increased information-processing demands and information asymmetries, both of which might require outside managerial talent, leading to a loss of family control and less ability by family principals [26]. Lastly, internationalization requires increasing ties with foreign stakeholders, resources, and institutions, which also makes the family more dependent on human and relational capital outside the family circle [1].

On the opposite side, the learning capability is greater among FFs due to its greater commitment with the long-term firm goals. Reference [27] remark that the FF's specific advantages include a high level of trust, strong values and commitment. The long-term commitment of the members of the FF can help to assure potential partners and investors of the continuity of the process, and the high level of trust inside the firm can enhance the formation of outside network ties. Furthermore, FFs' managers ought to minimize the effect of features that will tend to impede their internationalization, such as different cultures or values. Underlining this argument, [28], basing their study on the familiness concept, and specifically on the F-PEC scale developed by [29], argue that the culture dimension (the overlap between the family values and those in the firm) is of great importance in FFs since it favors its internationalization. Moreover, this result shows that the long-term commitment of family SMEs can help to assure potential partners and investors of the continuity of the process, and the high level of trust inside the firm can enhance the formation of outside network ties. Furthermore, family firms' managers ought to minimize the effect of features that will tend to impede their internationalization, such as different cultures or values.

This argument stressing the high commitment of the FF employees to the organizational long-term firm performance indicators, among which the innovative activity stands out, may cause that there exists a learning-by-exporting effect on innovation among the FF. Therefore, we propose the following hypothesis:

H1: There is a learning-by-exporting effect on innovation in FFs

\subsection{Labor Flexibility}

Firm labor flexibility refers to the ability of the firm to respond to changing economic conditions. The numerical flexibility is the ability of firms to change the number of people they employ by using several flexible work practices [30]. Therefore, a firm that exports needs to adapt its workforce to foreign environments that may differ to the domestic one. According to this argument the firm numerical flexibility should favor its export activity.

How numerically flexible are the FFs? Reference [1] underline that the small size and the flexibility of the management teams in family firms allow them to react quickly to new international opportunities. This greater flexibility (compared to the non-FFs) suggests that FFs may have a better ability to adapt to the export market conditions. In this context, as [30] stress, among the human resource techniques that enable the firm to become more numerically flexible, the hiring of temporary workers stands out. Thus, and accepting the abovementioned arguments, we propose the following hypothesis:

$\mathrm{H} 2$ : The numerical flexibility of the FF (through the hir- 
ing of temporary workers) intensifies its export activity.

According to the "insider-outsider" model, the labor market, from where the firms hire its workforce, is divided between incumbent employees whose positions are protected by labor turnover costs (the insiders) and entrants (with low turnover cost) and unemployed workers [31]. The strategy recommended by the EU to improve the European firms' competitiveness (named flexicurity strategy) is aimed at reducing the divide between insiders and outsiders in the labor market so as to improve firms' use of human capital [8].

This recommendation from the EU is due to the fact that when employers, to reduce labor costs, make excessive use of outsiders, their incentive to invest in human capital shrinks, and they become less likely to implement forms of work organization that can lead to greater innovative activity This excessive resort to temporary workers (outsiders) may constraint formation policies (among other invests in human capital), and, therefore, the capacity of the workforce to learn from the firm exposure to the export markets ${ }^{3}[31]$.

When focusing on the link between the type of workforce within the firm and its innovative activity, [31] underline that the innovative activities take place mainly at the firm's core, where workers' contracts are generally long-term, not on its periphery, where workers generally have non-standard contracts (as these on a temporary basis). Therefore, using a high rate of temporary workers should be negatively linked to carrying out innovative activities. In this line, [30] find evidence showing that the use of temporary work is negatively related to the innovative activity.

All these arguments suggest a inverse relationship between the proportion of temporary workers within the firm and its capacity to learn-by-exporting, such as the following two hypothesis: first, in $\mathrm{H} 3$ the direct effect of the firm flexibility on its innovative performance is proposed, and next, in $\mathrm{H} 4$ the positive moderating impact of the firm flexibility on the learning-by-exporting effect stated in $\mathrm{H} 1$ is suggested:

H3: The numerical flexibility of the FF (through the hiring of temporary workers) constrains its innovative capacity.

H4: The numerical flexibility of the FF (through the hiring of temporary workers) moderates negatively the learning-by-exporting effect on its innovative capacity.

\section{Methodology}

\subsection{Data}

This study analyses data drawn from the Spanish Business Strategy Survey (SBSS), an institutional database that surveys a representative panel of manufacturing firms, during the period from 2001 to 2010. Since 1990, the SBSS has surveyed an average sample of 1800 firms every year by

\footnotetext{
${ }^{3}$ In this sense, Spain is a good setting to test such hypothesis, since its economy has the highest proportion of temporary employees in the EU $(27.10 \%$, compared to $15.90 \%$ in the EU15; 32).
}

distributing a questionnaire with 107 questions across 500 fields. The reference population is composed of firms with 10 or more employees in the Spanish manufacturing industry. The SBSS takes a broad sample of firms each year, among which an average response rate of $90 \%$ was gathered. This may be because public authorities have the power and the resources to secure a high level of participation, the survey achieves a high response rate, and the sample is sufficiently large and representative of the population. In conjunction with the quality of the information collected, these characteristics constitute the main advantage of using the secondary data produced by public agencies [31]. All of the information contained in the SBSS is subject to strict controls for validity and consistency.

Table 1. Sample population.

\begin{tabular}{|c|c|c|c|c|c|c|c|}
\hline Year & $\begin{array}{l}\text { Total of } \\
\text { firms }\end{array}$ & $\begin{array}{l}\text { Expor- } \\
\text { ters }\end{array}$ & $\begin{array}{l}\text { Non-exp } \\
\text { rters }\end{array}$ & $\begin{array}{l}\text { Innova- } \\
\text { tors }^{\text {a }}\end{array}$ & $\begin{array}{l}\text { Non-inn } \\
\text { vators }^{b}\end{array}$ & $\begin{array}{l}\text { Family } \\
\text { Firms }\end{array}$ & $\begin{array}{l}\text { yon-Fam } \\
\text { ily Firms }\end{array}$ \\
\hline 2001 & $\begin{array}{l}4,629 \\
(10 \%)\end{array}$ & $65.14 \%$ & $34.86 \%$ & $82.09 \%$ & $17.91 \%$ & $\begin{array}{l}34.51 \\
\%\end{array}$ & $65.49 \%$ \\
\hline 2002 & $\begin{array}{l}4,629 \\
(10 \%)\end{array}$ & $64.34 \%$ & $35.66 \%$ & $81.75 \%$ & $18.25 \%$ & $\begin{array}{l}34.02 \\
\%\end{array}$ & $65.98 \%$ \\
\hline 2003 & $\begin{array}{l}4,629 \\
(10 \%)\end{array}$ & $64.20 \%$ & $35.80 \%$ & $84.21 \%$ & $15.79 \%$ & $\begin{array}{l}41.38 \\
\%\end{array}$ & $58.62 \%$ \\
\hline 2004 & $\begin{array}{l}4,629 \\
(10 \%)\end{array}$ & $64.41 \%$ & $35.59 \%$ & $84.81 \%$ & $15.19 \%$ & $\begin{array}{l}41.70 \\
\%\end{array}$ & $58.30 \%$ \\
\hline 2005 & $\begin{array}{l}4,629 \\
(10 \%)\end{array}$ & $62.64 \%$ & $37.36 \%$ & $79.22 \%$ & $20.78 \%$ & $\begin{array}{l}44.95 \\
\%\end{array}$ & $55.05 \%$ \\
\hline 2006 & $\begin{array}{l}4,629 \\
(10 \%)\end{array}$ & $61.74 \%$ & $38.26 \%$ & $77.38 \%$ & $22.62 \%$ & $\begin{array}{l}49.30 \\
\%\end{array}$ & $50.70 \%$ \\
\hline 2007 & $\begin{array}{l}4,629 \\
(10 \%)\end{array}$ & $62.34 \%$ & $37.66 \%$ & $79.15 \%$ & $20.85 \%$ & $\begin{array}{l}51.55 \\
\%\end{array}$ & $48.45 \%$ \\
\hline 2008 & $\begin{array}{l}4,629 \\
(10 \%)\end{array}$ & $63.86 \%$ & $36.14 \%$ & $78.25 \%$ & $21.75 \%$ & $\begin{array}{l}50.35 \\
\%\end{array}$ & $49.65 \%$ \\
\hline 2009 & $\begin{array}{l}4,629 \\
(10 \%)\end{array}$ & $64.86 \%$ & $35.14 \%$ & $79.78 \%$ & $20.22 \%$ & $\begin{array}{l}48.97 \\
\%\end{array}$ & $51.03 \%$ \\
\hline 2010 & $\begin{array}{l}4,629 \\
(10 \%)\end{array}$ & $66.15 \%$ & $33.85 \%$ & $82.66 \%$ & $17.34 \%$ & $\begin{array}{l}50.69 \\
\%\end{array}$ & $49.31 \%$ \\
\hline Total & $\begin{array}{l}+6,290 \\
100 \%)\end{array}$ & $63.86 \%$ & $36.14 \%$ & $80.93 \%$ & $19.07 \%$ & $\begin{array}{l}50.69 \\
\%\end{array}$ & $49.31 \%$ \\
\hline
\end{tabular}

${ }^{I}$ Proportion of firms that carried out any of the following innovative activities: R\&D investment, Process Innovations or Product Innovations.

${ }^{2}$ Proportion of firms that didn't carried out any of the following innovative activities: R\&D investment, Process Innovations or Product Innovations.

Following [32], in Table 2 we report the average values of the firms' export propensity, innovation and the proportion of FFs, according to the two-digit industry in which they operate. By doing so, we aim to develop some perspective on the heterogeneity of the firms' export and innovation behavior across the industries. As [32, 33] point out, the results show the importance of the industry when explaining the firm innovative, export and productivity performance. Note that all the differences are significant, as shown by the Fischer statistics. It can be outlined the intense export propensity and the high innovative activity of the chemical products and motor vehicle industry. On the other hand, as the table 2 shows, those firms coming from the textile, leather, lumber and wood, and furniture and fixtures subsectors are of a family nature at a greatest extent. 
Table 2. Manufacturing sub-sectors breakdown.

\begin{tabular}{|c|c|c|c|c|c|c|c|}
\hline Manufacturing sub-sectors ${ }^{\mathrm{a}}$ & $\mathbf{N}(\%)^{b}$ & Exporters & Non-exporters & Innovators $^{c}$ & Non-innovators $^{\mathrm{d}}$ & $\begin{array}{l}\text { Family } \\
\text { Firms }\end{array}$ & $\begin{array}{l}\text { Non-Family } \\
\text { Firms }\end{array}$ \\
\hline 1. Meat products & $559(2.94)$ & $62.16 \%$ & $37.84 \%$ & $51.34 \%$ & $48.66 \%$ & $56.32 \%$ & $43.68 \%$ \\
\hline 2. Food and tobacco & $1,769(9.27)$ & $54.62 \%$ & $45.38 \%$ & $54.29 \%$ & $45.71 \%$ & $48.64 \%$ & $51.36 \%$ \\
\hline 3. Beverages & $426(2.24)$ & $69.70 \%$ & $30.30 \%$ & $65.02 \%$ & $34.98 \%$ & $23.24 \%$ & $76.76 \%$ \\
\hline 4. Textile & $1,410(7.42)$ & $58.30 \%$ & $41.70 \%$ & $46.67 \%$ & $53.33 \%$ & $62.82 \%$ & $37.18 \%$ \\
\hline 5. Leather products & $496(2.61)$ & $62.65 \%$ & $37.35 \%$ & $44.35 \%$ & $55.65 \%$ & $62.03 \%$ & $37.97 \%$ \\
\hline 6. Lumber and wood & $683(3.60)$ & $49.49 \%$ & $50.51 \%$ & $45.68 \%$ & $54.32 \%$ & $60.03 \%$ & $39.97 \%$ \\
\hline 7. Paper products & $605(3.18)$ & $69.80 \%$ & $30.20 \%$ & $51.74 \%$ & $48.26 \%$ & $37.82 \%$ & $42.18 \%$ \\
\hline 8. Printing and publishing & $955(5.03)$ & $45.22 \%$ & $54.78 \%$ & $37.49 \%$ & $62.51 \%$ & $47.65 \%$ & $52.35 \%$ \\
\hline 9. Chemical products & $1,288(6.78)$ & $84.77 \%$ & $15.23 \%$ & $78.88 \%$ & $21.12 \%$ & $26.32 \%$ & $73.68 \%$ \\
\hline $\begin{array}{l}\text { 10. Rubber and miscellaneous } \\
\text { plastics products }\end{array}$ & $967(5.09)$ & $77.13 \%$ & $22.87 \%$ & $60.29 \%$ & $39.71 \%$ & $45.62 \%$ & $54.38 \%$ \\
\hline $\begin{array}{l}\text { 11. Mining and quarrying of } \\
\text { non-metallic minerals (no fu- } \\
\text { els) }\end{array}$ & $1,495(7.87)$ & $45.58 \%$ & $54.42 \%$ & $48.16 \%$ & $51.84 \%$ & $48.95 \%$ & $51.05 \%$ \\
\hline 12. Primary metal industries & $637(3.35)$ & $83.39 \%$ & $16.61 \%$ & $64.99 \%$ & $35.01 \%$ & $24.15 \%$ & $75.85 \%$ \\
\hline 13. Fabricated metal products & $2,415(12.71)$ & $49.15 \%$ & $50.85 \%$ & $49.03 \%$ & $50.97 \%$ & $53.63 \%$ & 46.37 \\
\hline $\begin{array}{l}\text { 14. Industrial machinery and } \\
\text { equipment }\end{array}$ & $1,289(6.79)$ & $78.31 \%$ & $21.69 \%$ & $67.03 \%$ & $32.97 \%$ & $43.18 \%$ & $56.82 \%$ \\
\hline $\begin{array}{l}\text { 15. Computer and office } \\
\text { equipment }\end{array}$ & $294(1.55)$ & $74.35 \%$ & $25.65 \%$ & $69.39 \%$ & $30.61 \%$ & $45.41 \%$ & $54.59 \%$ \\
\hline 16. Electrical equipment & $1,016(5.35)$ & $74.71 \%$ & $25.29 \%$ & $73.03 \%$ & $27.97 \%$ & $37.53 \%$ & $62.47 \%$ \\
\hline 17. Motor vehicles & $954(5.02)$ & $88.26 \%$ & $11.74 \%$ & $78.30 \%$ & $22.70 \%$ & $20.76 \%$ & $79.24 \%$ \\
\hline $\begin{array}{l}\text { 18. Other transportation } \\
\text { equipment }\end{array}$ & $441(2.32)$ & $72.35 \%$ & $27.65 \%$ & $70.98 \%$ & $29.02 \%$ & $33.63 \%$ & $66.37 \%$ \\
\hline 19. Furniture and fixtures & $941(4.95)$ & $56.03 \%$ & $43.97 \%$ & $46.44 \%$ & $53.56 \%$ & $63.02 \%$ & $36.98 \%$ \\
\hline $\begin{array}{l}\text { 20. Miscellaneous manufactur- } \\
\text { ing industries }\end{array}$ & $365(1.92)$ & $75.00 \%$ & $25.00 \%$ & $47.12 \%$ & $52.88 \%$ & $54.92 \%$ & $45.08 \%$ \\
\hline Total & $100 \%$ & $63.91 \%$ & $36.09 \%$ & $56.73 \%$ & $43.27 \%$ & $45.94 \%$ & $54.06 \%$ \\
\hline $\mathrm{F}$ & & $82.88 * * *$ & & $63.52 * * *$ & & $58.76^{* * *}$ & \\
\hline
\end{tabular}

${ }^{* * *} p<0.01 ; * * p<0.05 ;{ }^{*} p<0.1$.

${ }^{a}$ Sub-sectors are from SIC categories adapted from CNAE'93 classification.

${ }^{b}$ Number of observations during the ten years (2001-2010) included in the analysis.

${ }^{c}$ Proportion of firms that carried out any of the following innovative activities: R\&D investment, Process Innovations or Product Innovations.

${ }^{d}$ Proportion of firms that didn't carried out any of the following innovative activities: $R \& D$ investment, Process Innovations or Product Innovations.

\subsection{Measurement of Variables}

\subsubsection{Export Activity}

The variables used in this analysis to measure the firm export activity are export propensity (PX) and export intensity (IE). PX is a categorical variable indicating whether the firm exported during the period considered. IE represents the exports made as a proportion of total sales. This ratio is used in the majority of studies about the export orientation of the firm [3], and has also been used to study the hypothesis of learning-by-exporting [17].

\subsubsection{Numerical Flexibility}

Hiring temporary workers is one main human resource practice that enables the firm to become more numerical flexible [30]. Thus, these firms in where their workforce is significantly composed by employees on a temporary basis will be more capable to adapt to different environments, what suggest that this variable will be important when explaining the firm export activity. So, we have also used the number of temporary workers, measured as the percentage of the workforce employed in a temporary capacity on 31 st December.

\subsubsection{Innovation}

In the first place, the firm innovative activity has been approached through measuring the $\mathrm{R} \& \mathrm{D}$ investment with a quantitative variable (IDV) which expresses the total costs of R \& D as a percentage of total sales. This measure has been used in the majority of previous studies, for example in 


\section{[34] or in [35].}

Additionally, and in line with the recommendations of the literature [36], this measure of innovation was complemented with an evaluation of the outputs of innovation. The use of this subjective evaluation is due to the fact that the patents and other objective measures do not really reflect the total on innovations, many of which are not registered [37]. Moreover, as [38] argue, the use of R \& D expenditure alone to measure innovation is inadequate because of the "conceptual and statistical weakness of this variable in terms of the outputs of innovation, owing to the fact that this measure is rarely used, the long periods between such investments, and the exogenous relationship between coordination and the influence of the outputs". Therefore, we have measured the principal outputs of innovation - product (IP) and process (IPr) innovation- using a dichotomous variable that takes the value 1 if the firm has produced the corresponding output of innovation, and 0 otherwise.

\subsubsection{Family Firm}

The FF status was not included in our regressions as independent variable, but since this work focuses on FFs, the sample is filtered with this variable. In doing so, I select these firms meeting the following criteria ${ }^{4}$ [14]. According to these authors' definition, to have the family consideration, what matters is that the firm belongs to a family with one or more members occupying managerial positions. Thus, I consider these firms in which the family owns a significant part of the family that allows the family controlling the firm and in which such family also contains at least one member managing the organization.

\subsubsection{Control Variables}

As control variables, the size, age, the foreign shareholder, the industry's technological intensity and the firm productivity were included in the empirical analysis. First, the size of the firm is taken as the total number of employees in the firm on the 31st December of the year considered, and age was taken as the number of years of operation of the firm; second, having a foreign firm as a shareholder enables the organization to access to more resources and, therefore, to be in a better position to enter the export markets [14]. Thus, the foreign participation in the firm ownership is measured by quantifying the proportion of the firm capital is held by foreign agents; on the other hand, one must account for the industry's technological sophistication when considering the firm's international strategy [39-40, 6, 23]. In accordance with these studies, we controlled for the industry's technological intensity (ITI) by employing a dummy variable that indicates whether the firm belongs to an industry with higher R\&D expenses than those of the average industry; and finally, to measure productivity, we have used the value of hourly productivity $(\mathrm{PH})$ that is cal-

\footnotetext{
4 As can be seen in table 2, approximately half of the firms
} within the sample were considered as FFs. culated as the added value divided by the approximate Hours Effectively Worked (the units of the hourly productivity may be interpreted as thousands of Euros per 1,000 hours. This variable was only calculated for firms where the added value was not negative).

Table 3. Summary of the measurement of the variables.

\begin{tabular}{|c|c|}
\hline Variables & Measurement \\
\hline Export Propensity & $\begin{array}{l}\text { Categorical variable that indicates whether the } \\
\text { firm has exported. Categories of the variable: } \\
\text { Yes/No. }\end{array}$ \\
\hline Family Firm status & $\begin{array}{l}\text { Categorical variable that indicates whether the } \\
\text { firm is of family nature. Categories of the variable: } \\
\text { Yes/No. }\end{array}$ \\
\hline R\&D Investment & $\begin{array}{l}\text { Percentage that represents the firm's total R\&D } \\
\text { expenses over its total sales }\end{array}$ \\
\hline Product Innovations & $\begin{array}{l}\text { Categorical variable that indicates whether the } \\
\text { firm has achieved product innovations during the } \\
\text { financial year. Categories of the variable: Yes/No. }\end{array}$ \\
\hline Process Innovations & $\begin{array}{l}\text { Categorical variable that indicates whether the } \\
\text { firm has achieved process innovations during the } \\
\text { financial year. Categories of the variable: Yes/No. }\end{array}$ \\
\hline Temporary Workers & $\begin{array}{l}\text { Percentage of the eventual personnel over the total } \\
\text { personnel employed at the firm as of December } \\
31^{\text {st }}\end{array}$ \\
\hline Foreign Shareholding & $\begin{array}{l}\text { Percentage of the property owned by foreign } \\
\text { agents }\end{array}$ \\
\hline $\begin{array}{l}\text { Industry's Technologi- } \\
\text { cal Intensity }\end{array}$ & $\begin{array}{l}\text { Categorical variable that indicates whether the } \\
\text { firm belongs to a subsector whose average value of } \\
\text { R\&D expenses is higher than the average value of } \\
\text { R\&D expenses of all of the subsectors in the sam- } \\
\text { ple. Categories of the variable: Yes/No. }\end{array}$ \\
\hline Export Distance & $\begin{array}{l}\text { Distance between the export's country of origin } \\
\text { (i.e., Spain) and the export's destination. To meas- } \\
\text { ure the distances, we obtained information from } \\
\text { the French Research Center in International Eco- } \\
\text { nomics (CEPII). To determine the country of des- } \\
\text { tination for each sub-sector's exports, we obtained } \\
\text { information from the Spanish Institute for External } \\
\text { Trade (Icex) }\end{array}$ \\
\hline Hourly Productivity & $\begin{array}{l}\text { Added value divided by the approximate number } \\
\text { of hours effectively worked The units of the hourly } \\
\text { productivity measure may be interpreted in terms } \\
\text { of thousands of Euros per } 1000 \mathrm{~h} \text {. This measure } \\
\text { also considered firms with non-negative added } \\
\text { values. }\end{array}$ \\
\hline Size & $\begin{array}{l}\text { Total personnel employed at the firm as of De- } \\
\text { cember } 31 \text { st }\end{array}$ \\
\hline Age & Year in which the firm was incorporated \\
\hline
\end{tabular}

Finally, I also control for the sub-sector in which the firm operates and for the year of operation. A dummy variable was used to control for sub-sector, based on the three digit classification of industrial activities used in the CNAE-93 classification of the twenty manufacturing sectors.

\subsection{Model Specifications}

Since I want to study the causal impact of two main variables (proportion of temporary workers and the firm export propensity) on two dependent ones (on the export activity 
when referring to the first one, and on the innovative activity, when analyzing the learning-by-exporting effect), I lagged for one period the previously mentioned variables. Furthermore, by introducing lagged variables ${ }^{5}$. the possible problems of covariance are reduced [41], at the same time as possible inferences of a causal relationship are improved [42].

To analyze the relationships under study, two kinds of effects (direct and moderated) are studied. Following [43] and [44], to estimate the dependent variable, probit and tobit regressions were used ${ }^{6}$ : when the dependent variable is categorical (in this case, export propensity, product and process innovations) probit regression is used, while when the dependent variable is quantitative (in this work, export intensity and R\&D investments), tobit is the appropriate model to use $[44]^{7}$. When trying to explain the export intensity, the firms that have not exported at all in the period under consideration are omitted. It is important to note that the final sample has been filtered by the variable indicating whether the firm is of family nature. First, to test both the hypothesis of learning-by-exporting on innovation (H1), and this exerted by the proportion of temporary workers within the workforce on the firm innovative performance (H3), I suggest using a tobit model specified as follows when the dependent variable is the R\&D investment:

$$
\begin{gathered}
R D I_{t=} \beta_{0}+\beta_{1} \text { Cont }_{t}+\beta_{2} E P_{t-1}+\beta_{3} \text { Temp }_{t-1}+\propto_{i}+ \\
\varepsilon_{i t} ; i=1, \ldots, n ; t=1, \ldots, T_{i}
\end{gathered}
$$

where the control covariates are the firm size, age, the industry's technological intensity, the foreign shareholder, hourly productivity and dummies for sectors and years; regarding the explanatory variables, $\mathrm{EP}_{\mathrm{t}-1}$ is the firm Export Propensity, lagged one period, it is in year $\mathrm{t}-1$, while Temp is the proportion of temporary workers, also in period $\mathrm{t}-1$. Ai captures the unobservable differences between firms; and, finally, $\varepsilon_{i t}$ is the error term. It is assumed that $\alpha_{i}$ and $\varepsilon_{i t}$ are uniformly, independently and normally distributed with a mean of zero and variance $\sigma_{\alpha}^{2}$ and $\sigma_{\varepsilon}^{2}$ respectively, and are independent of $\left(x_{i 1}, x_{i 2}, \ldots, x_{i T}\right)$. Nevertheless, when the dependent variable is of categorical nature (product/process innovations), a probit model is analyzed:

$$
I N N O V_{t}=
$$

\footnotetext{
${ }^{5}$ Following the recommendations of [4], in the relationship between innovation and the firm export behaviour, lagging the independent variables for longer periods does not have a significant effect.

${ }^{6}$ In the different regressions the tests of Breusch-Pagan-Godfrey, of White and of Levene have been applied, confirming that the estimation of the errors are random, which is to say there is heteroskedasity. To correct for this, robust estimates of error have been used to calculate the coefficients using ordinary least squares.

${ }^{7}$ As [34], [43] and [44], to contrast the convenience of a tobit analysis for both types of dependent variables, a test has been employed based on the likelihood ratio (LR). The result of the LR test is in agreement with the findings of earlier works, overcoming the implicit restriction in the tobit estimator, and in that way indicating the need to use a separate (unrestricted) probit model, and another (restricted) tobit model.
}

$$
\begin{gathered}
1 \text {, if } \beta 0+\beta 1 \text { Contt }+\beta 3 \text { EPt- } 1+\beta 2 \text { Tempt }-1+\alpha i+\text { sit } \geq 0 ; \\
i=1, \ldots, n ; t=1, \ldots, \text { Ti } \quad 0, \text { otherwise } \\
\text { INNOV }= \\
1 \text {, if } \beta 0+\beta 1 \text { Contt }+\beta 3 \text { EPt- } 1+\beta 2 \text { Tempt }-1+\propto i+\text { cit } \geq 0 ; \\
i=1, \ldots, n ; t=1, \ldots, T i \quad 0, \text { otherwise }
\end{gathered}
$$

where INNOV means product innovations or process innovations in period $t$; Cont $t_{t}$ are the control variables, it is the firm age, size, foreign shareholder, industry's technological intensity, hourly productivity and dummies for sectors and years, all for the period t. Next, the model includes two explanatory covariates, both lagged one period: the firm Export Propensity (EP) and the proportion of temporary workers. Finally, $\alpha_{i}$ and $\varepsilon_{i t}$ express the unobservable differences between firms and the error term, respectively.

On the other hand, in order to test $\mathrm{H} 3$, it is, the direct impact of the firm numerical flexibility on the firm export activity, the model take two different specifications, depending on the type of dependent variable:

First, when the Export Activity indicator that wants to be explained is the firm Export Intensity (EI), a tobit model is operationalized in the following way:

$$
\begin{array}{r}
E I_{t=} \beta_{0}+\beta_{1} \text { Cont }_{t}+\beta_{2} \text { Temp }_{t-1}+\propto_{i}+\varepsilon_{i t} i= \\
1, \ldots, n ; t=1, \ldots, T_{i} \quad \text { (3) }
\end{array}
$$

being the control variables the firm age, size, foreign shareholder, industry's technological intensity, hourly productivity and dummies for sectors and years, all for the period t. In this case, the dependent variable is the proportion of temporary workers lagged one year; meanwhile, $\alpha_{i}$ and $\varepsilon_{i t}$ are the same as usual.

Nevertheless, when the dependent variable is the EP (Export Propensity) in the period t, a probit model as the following is recommendable:

$$
\begin{gathered}
E P_{t} \\
\quad\left\{\begin{array}{c}
1, \text { if } \beta_{0}+\beta_{1} \text { Cont }_{t}+\beta_{2} \text { Temp }_{t-1}+\propto_{i}+\varepsilon_{i t} \geq 0 \\
i=1, \ldots, n ; t=1, \ldots, T_{i}
\end{array}\right. \\
0, \text { otherwise }
\end{gathered}
$$

$$
\operatorname{INNOV}_{t}=
$$

where Cont $\mathrm{t}_{\mathrm{t}}$ are the same control variables as in the rest of the models; the explanatory variable correspond to the period $\mathrm{t}-1$ and is the proportion of temporary workers within the firm (measure for its numerical flexibility); finally $\alpha_{i}$ captures the unobservable differences between firms; and, $\varepsilon_{i t}$ is the error term.

The analysis of the moderating effect (H4) is conducted by studying the possible interactions between the two main explanatory variables of our model: the proportion of temporary workers and the firm export activity. The goal that wants to be achieved in doing it so, is to study how the firm numerical flexibility moderates the learning-by-exporting effect on the firm innovation. 


\subsection{Endogeneity Concern}

All of the abovementioned empirical models are static. Nevertheless, a large body of empirical evidence suggests that a firm's past export experiences may influence the firm's future export decisions [45]. Following the same perspective, [46] shows that past product and process innovations affect the probability of obtaining product and process innovations. To account for the existence of simultaneity in both effects, we consider the multi-step case by including both the lagged export status of the firm and the two lagged innovation outputs to the simple-period case.

When studying the direction of causality with regard to the two hypotheses, we may face an endogeneity problem because one of our main explanatory variables (the export activity in models 1 and 4) may be modified by the outcome: this is our dependent variable in models 1 and 4 (innovation) impact on the independent one of such models (Export propensity, EP). This hypothesis is the so-named self-selection one: the export markets select the best performing firms [2].

To address this concern, we use the following strategy: first, we instrumentalize EP and run a 2SLS regression for the static case, according to [47]'s method. Next, for the dynamic one, we lag the independent variables for the convenient period, carrying out a [48]'s GMM model. Thus, our primary concern is identifying a valid instrument for the 2SLS model. As [49] point out, a firm's export status should be strongly negative correlated with the distance between its geographical location and the potential destination for its products, as transportation costs generally increase with distance. From the Spanish Institute for Foreign Trade (ICEX), we obtained information about the first 10 countries to which the firms of the 20 manufacturing sub sectors in our sample exported during the period 2001-2010. We used this information to determine the weight of each country $\left(\mathrm{w}_{\mathrm{ij}}\right)$. To calculate the distance between the origin of the export (i.e.,Spain) and the destination of the export $\left(\mathrm{d}_{\mathrm{oj}}\right)$, I employed the distances supplied by the French Research Center in International Economics (CEPII) website. These distances were computed by using the great circle distances procedure. We formulate the formal equation of the instrumental variable representing the export distance between Spain and the destination country (ExpDist) as follows:

$\sum_{j=1}^{10} W_{i j} d_{o j}$ where $\mathrm{d}_{\mathrm{oj}}$ is the great circle distance between the country of origin and the export destination $\mathrm{j}$. (Export $/ \sum_{j=1}^{10}$ Export $_{i j)}$ is the weight of country $\mathrm{j}$ on the total exports of sector i (i.e., the first ten destination countries for sector i), [49]. For the multi-period case, we obtained GMM estimates by using [48]'s first-difference GMM estimator, where the instruments are all right-hand-side variables lagged three times or more. The third lag of the first difference of the explanatory endogenous variables is required because it is not correlated with the current error term whereas the first and second lags are. Generally, one can experiment with a second or deeper lag to find a good instrument, but using deeper lags reduces the size of the sample. If the number of firms is large enough (as in this work) it shouldn't be used all of the available lags as instruments.

\section{Results}

Table 4 provides information about the means, standard deviations, and correlations between the variables. Most of the values are below 0.56 , which is the maximum value recommended for the test of multi-colinearity $[50,4]$. In no case are correlations found to be higher than that level. Therefore, it can be presumed that the impact of these correlations can be evaluated using a test for inflation of variance (VIF). It can be seen that the maximum VIF is $1.39^{8}$. These levels are considerably lower than 10, a level that suggests that the results are not biased by multi-colinearity [42].

Table 4. Means, standard deviations and correlations.

\begin{tabular}{|c|c|c|c|c|c|c|c|c|c|c|c|c|}
\hline & Mean & SD & 1 & 2 & 3 & 4 & 5 & 6 & 7 & 8 & 9 & 10 \\
\hline 1. EP & 0.64 & 0.48 & & & & & & & & & & \\
\hline 3. RDI & 0.74 & 2.67 & $.13^{*}$ & & & & & & & & & \\
\hline 4. PI & 0.21 & 0.40 & $.25^{*}$ & $.22 *$ & & & & & & & & \\
\hline 5. PrI & 0.31 & 0.46 & $.21^{*}$ & $.12 *$ & $.36 *$ & & & & & & & \\
\hline 6. Temp & p13.01 & 17.81 & $-.11 *$ & $-.04 *$ & $*-.02 *$ & $* .02 *$ & & & & & & \\
\hline 7. Prop & 18.02 & 37.38 & $.31 *$ & $.06^{*}$ & $.13 *$ & $.13^{*}$ & $-.11 *$ & & & & & \\
\hline 8. ITI & 0.28 & 0.45 & $.21 *$ & $.24 *$ & $.18 *$ & $.11^{*}$ & $-.09 *$ & * $.24 *$ & & & & \\
\hline $\begin{array}{l}\text { 9. Ex- } \\
\text { pDist }\end{array}$ & 176.17 & 745.93 & $.02 *$ & $.08 *$ & .00 & $-.02 *$ & -.01 & -.00 & $.19^{*}$ & & & \\
\hline 10. Pro & 27.51 & 24.29 & $.23 *$ & $.06^{*}$ & $.10 *$ & $.14^{*}$ & $-.13 *$ & * $.26^{*}$ & $.12 *$ & $.11 *$ & & \\
\hline 11. Size & $\mathrm{e}^{4} 4.23$ & 1.50 & $.49 *$ & $.16^{*}$ & $.29 *$ & $.29^{*}$ & .01 & $.48 *$ & $.21 *$ & -.00 & $.33^{*}$ & \\
\hline 12. Age & é2.98 & 0.80 & $.22 *$ & $.07 *$ & $.09 *$ & $.06^{*}$ & $-.19 *$ & * $.15^{*}$ & $.07 *$ & $.03 *$ & $.19 *$ & $.27 *$ \\
\hline
\end{tabular}

$* p<0.05$

$E P=$ Export Propensity $;$ Fam $=$ Family Firm status $; R D I=R \& D$ Investment; $P I=$ Product Innovations; $P r I=$ Process Innovations; Temp=Temporary Workers; Prop = Foreign Shareholding; ITI=Industry's Technological Intensity; ExpDist=Export Distance; Prod=Hourly Productivity.

${ }^{a}$ Size and age are taken as natural logarithms

\subsection{Descriptives}

Following, some previous means differences analyses (ANOVA) are carried out to check how the FF (in comparison to the non-FF) behaves in terms of its export, innovative activity (according to both its R\&D investment and its gathering of innovation outputs) and its numerical flexibility

\footnotetext{
${ }^{8}$ Maximum VIF for each variable when independent (there is a different VIF for each regression): Export Propensity=1.28; Temporary Workers=1.13; Foreign Shareholding=1.03; Industry's Technological Intensity=1.11; Export Distance=1.10; Hourly Productivity $=1.15 ;$ Size=1.39; Age=1.19.
} 
(measured through its proportion of temporary workers).

Table 5. Main features of the firm according to its family status.

\begin{tabular}{|c|c|c|c|c|c|c|}
\hline & $\begin{array}{l}\text { Export } \\
\text { tensity }^{a}\end{array}$ & $\begin{array}{l}\text { IExport } \\
\text { Propensity }^{\text {b }}\end{array}$ & $R \& D^{a}$ & $\begin{array}{l}\text { Product } \\
\text { Innova- } \\
\text { tions }^{\text {b }}\end{array}$ & $\begin{array}{l}\text { Process } \\
\text { Innova- } \\
\text { tions }^{b}\end{array}$ & $\begin{array}{l}\text { Tempo- } \\
\text {-rary } \\
\text { workers }^{a}\end{array}$ \\
\hline $\begin{array}{l}\text { Family } \\
\text { Firms }\end{array}$ & 12.07 & $51.34 \%$ & 0.54 & $16.12 \%$ & $26.57 \%$ & $13.60 \%$ \\
\hline $\begin{array}{l}\text { Non-Fan, } \\
\text { ily Firms }\end{array}$ & 25.90 & $74.27 \%$ & 0.91 & $24.46 \%$ & $34.48 \%$ & $13.09 \%$ \\
\hline $\mathrm{F}$ & $1,234.18$ & ${ }^{*} 1,045.78 * * *$ & $83.94 * * *$ & $185.38 * * *$ & $127.79 * *$ & $=3.02 *$ \\
\hline
\end{tabular}

$* * * p<0.01 ; * * p<0.05 ; * p<0.1$.

${ }^{a}$ Mean value

${ }^{b}$ Proportion of firms developing the correspondent activity

As can be seen in table 5, the results show that FFs undertake significatively lesser export and innovative activities, for every measure included to approach both variables. Nevertheless, FFs hire more (but not at a great extent) temporary workers than non-FFs, what makes them to be considered as more numerical flexible organizations, according to such human resource practice. All these descriptive previous tests are valuable to depict broadly the outlook dealing with the FF behaviour in terms of the variables considered. However, to study the proposed hypothesis, some different analyses are required. To this end, I perform different random effects tobit and probit regressions in the next section.

\subsection{Main Analyses}

As explained in the Methodology section, to test the fulfillment of the proposed relationships I run several random effects (to account for the firm heterogeneity) probit and tobit regressions. Next the main results are displayed and the implications concerning the hypotheses are explained.

Table 6. Previous Numerical Flexibility/Export Propensity (learning-by-exporting) $\rightarrow$ innovation (R\&D investment) in FFs.

\begin{tabular}{|c|c|c|c|c|c|}
\hline & \multicolumn{2}{|c|}{ Simple period case } & \multicolumn{3}{|c|}{ Multi period case } \\
\hline Export Propensity $_{t-1}$ & $1.98 * * *(0.29)$ & $2.02 * * *(0.15)$ & $1.55 * * *(0.23)$ & $1.63 * * *$ & $(0.26)$ \\
\hline Numerical Flexibility $_{t-1}$ & $-0.02 * *(0.01)$ & $-0.01 \quad(0.01)$ & $-0.01 * * \quad(0.01)$ & -0.01 & $(0.01)$ \\
\hline R\&D Investment $t_{t-1}$ & & & $1.29 * * *(0.04)$ & $0.65 * * *$ & $(0.04)$ \\
\hline Size $^{a}$ & $1.82 * * *(0.15)$ & $1.83^{* * *}(0.15)$ & $1.29 * * *(0.11)$ & $1.29 * * *$ & $(0.11)$ \\
\hline $\operatorname{Age}^{a}$ & $-0.28 \quad(0.22)$ & $-0.28 \quad(0.23)$ & $(0.16)$ & -0.12 & $(0.16)$ \\
\hline Foreign Shareholder & $-0.01 \quad(0.01)$ & $-0.01 \quad(0.01)$ & $-0.00 \quad(0.01)$ & -0.00 & $(0.01)$ \\
\hline Industry's Tech. Intensity & $1.55 * * *(1.50)$ & $1.53 * * *(1.50)$ & $0.47 \quad(1.20)$ & -0.99 & $(1.26)$ \\
\hline Labour Productivity & $0.01 * *(0.01)$ & $0.01 * *(0.01)$ & $0.01 * * \quad(0.01)$ & $0.01 * *$ & $(0.01)$ \\
\hline Export Prop.t-1X Num. Flex.t-1 & & $-0.00 \quad(0.01)$ & & -0.00 & $(0.01)$ \\
\hline Sector Dummies & Yes & Yes & Yes & Yes & \\
\hline Industry Dummies & Yes & Yes & Yes & Yes & \\
\hline Number of observations & 5,876 & 5,876 & 5,871 & 5,871 & \\
\hline Log likelihood & $-4,331.05$ & $-4,331.02$ & $-4,182.62$ & $-4,184.4$ & \\
\hline Wald $\mathrm{Chi}^{2}$ & $421.05 * * *$ & $421.60 * * *$ & $975.76^{* * *}$ & $977.40 *$ & \\
\hline
\end{tabular}

Dependent variable: R\&D investment. Random effects tobit regression.

Censored regression. Left censored observations=4,569/4,566; Uncensored observations=1,307/1,305.

All regressions include a constant. The coefficients are marginal effects and represent the change in probability due to a one-standard deviation increase in the independent variable at the means of the other variables (or the change from 0 tol in the case of a dummy variable). Standard errors are reported in parentheses.

* Significant at 10\%level; ** Significant at 5\% level; *** Significant at 1\%. 
First, as can be seen in table 6, the firm Export Propensity exerts a positive and significant effect on innovation when it is approached through the $\mathrm{R} \& \mathrm{D}$ investment. When analyzing the impact on the two considered outpus (product and process innovations), the result is the same. Taking into account these findings, it can be concluded that there exist a learning-by-exporting effect on innovation, as proposed in H1.

When looking at the coefficient of the numerical flexibility on the firm innovative activity, a negative impact on the R\&D investment can be seen. This confirms H3, that suggested a negative causal effect of the proportion of temporary workers (remember that since this routine was used to become more numerical flexible, the former concept is measured by this practice) and the innovation carried out within the FF. Nevertheless, as can be seen in table 7, the effect exerted by the firm numerical flexibility on the innovation outcomes (product and process innovations) is non-significant. Therefore, H3 is accepted, but only partially.

Regarding the analysis of the moderating effect exerted by the numerical flexibility on the learning-by-exporting effect on innovation proposed in H1, in both tables 6 and 7 it can be seen that such moderating impact is non-significant for every interactions between the previously mentioned covariate and the firm EP. Taking into account these results, $\mathrm{H} 4$ is rejected.

Next, to check the robustness to endogeneity of all these findings, I face such concern on the learning by exporting effect on innovation. If the problem exists, it would mean that the export activity is influenced by the output of our model: the innovative activity, what means that there would be a self-selection effect on innovation. That would mean that there may be a self-selection effect since the export markets select the best performers, in our case, those innovative firms. To address this endogeneity problem, I carry out a Durbin-Wu-Hausman test, that consists in checking whether the residuals obtained from the regression are significant in the OLS basic model for the dependent variables. At a significance level of $p=0.05$, the coefficient of the residuals were not significant for neither the R\&D investment $(p=21)$, nor any of the innovation outputs (both product $(p=0.08)$ and process innovation, $p=0.65)$. This evidence suggests that EP does not show an endogeneity problem when analyzing the learning-by-exporting effect and, therefore, there is no need to follow an instrumental variable strategy (2SLS and GMM) to check for the robustness results. Similarly, Bratti and Felice (2010) also conclude that the firm export activity was exogenous to the learning effect exerted by this variable on the firm's innovative capacity, when controlling for the labor productivity.

On the other hand, $\mathrm{H} 2$ stated the positive causal effect of the firm numerical flexibility and the firm export activity. As said before, being more flexible makes the firm to be able to react quicker to the environmental changes and adapt in a better position to different contexts. All this should favor the firm export activity. Nevertheless, it can be seen in table 8 that the impact exerted by the firm numerical flexibility is negative, contrary to what was expected. Thus, H2 is rejected.

Table 8. Previous Numerical Flexibility $\rightarrow$ Export Activity (Export Intensity/Export Propensity) in FFs.

\section{Simple period case Multi period case}

Dependent variable: Export Intensity (random effects tobit regression) ${ }^{\mathrm{a}}$

\begin{tabular}{|c|c|c|}
\hline Numerical Flexibility ${ }_{t-1}$ & $-0.05^{*} \quad(0.02)$ & $-0.06 * * *(0.02)$ \\
\hline Export Intensity $_{t-1}$ & & $0.70 * * *(0.02)$ \\
\hline Controls as in Table $6^{\mathrm{b}}$ & Yes & Yes \\
\hline Sector Dummies & Yes & Yes \\
\hline Industry Dummies & Yes & Yes \\
\hline Number of observations & 5,883 & 5,881 \\
\hline Log likelihood & $-13,345.71$ & $-12,281.85$ \\
\hline Wald Chi ${ }^{2}$ & $532.50 * * *$ & $2,669.22 * * *$ \\
\hline
\end{tabular}

Dependent variable: Export Propensity ${ }_{t}$ (random effects probit regression)

\begin{tabular}{|c|c|c|}
\hline Numerical Flexibility $_{t-1}$ & $-0.01 * \quad(0.00)$ & $-0.01 * \quad(0.00)$ \\
\hline Export Propensity $_{t-1}$ & & $2.88^{* * *}(0.06)$ \\
\hline Controls as in Table $6^{b}$ & Yes & Yes \\
\hline Sector Dummies & Yes & Yes \\
\hline Industry Dummies & Yes & Yes \\
\hline Number of observations & 5,884 & 5,884 \\
\hline Log likelihood & $-1,748.61$ & $-1,248.79$ \\
\hline Wald $\mathrm{Chi}^{2}$ & $565.01 * * *$ & $3,140.71 * * *$ \\
\hline
\end{tabular}

All regressions include a constant. The coefficients are marginal effects and represent the change in probability due to a one-standard deviation increase in the independent variable at the means of the other variables (or the change from 0 to 1 in the case of a dummy variable). Standard errors are reported in parentheses.

\footnotetext{
* Significant at $10 \%$ level; ** Significant at $5 \%$ level. ***Significant at $1 \%$

${ }^{a}$ Censored regression. Left censored observations $=2,864$; Uncensored observations $=3,019$.
}

${ }^{b}$ The control variables are the same as in Table 6: log of size, log of age, foreign shareholders, temporal workers, industry's technological intensity and labor productivity. 
Table 7. Previous Numerical Flexibility/Export Propensity (learning-by-exporting) $\rightarrow$ innovation (Product/Process Innovations) in FFs.

\begin{tabular}{|c|c|c|c|c|}
\hline & $\begin{array}{l}\text { Simple period case } \\
\text { (1) }\end{array}$ & (2) & $\begin{array}{l}\text { Multi period case } \\
\text { (1) }\end{array}$ & (2) \\
\hline \multicolumn{5}{|c|}{ 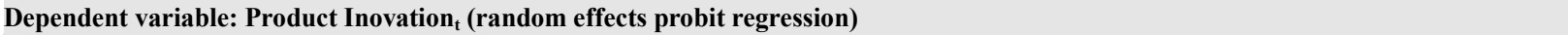 } \\
\hline Export Propensity $_{\mathrm{t}-1}$ & $0.54 * * *(0.10)$ & $0.49 * * *(0.12)$ & $0.34 * * *(0.07)$ & $0.34 * * *(0.07)$ \\
\hline Numerical Flexibility ${ }_{t-1}$ & $-0.01 \quad(0.02)$ & $-0.00 \quad(0.00)$ & $-0.00 \quad(0.00)$ & $-0.00 \quad(0.00)$ \\
\hline Export Prop.t-1X Num. Flex.t-1 & & $(0.00)$ & & $(0.00)$ \\
\hline Product Innovations $\mathrm{t}_{\mathrm{t}-1}$ & & & $1.54 * * *(0.07)$ & $1.54 * * *(0.07)$ \\
\hline Controls as in Table 6 & Yes & Yes & Yes & Yes \\
\hline Sector Dummies & Yes & Yes & Yes & Yes \\
\hline Industry Dummies & Yes & Yes & Yes & Yes \\
\hline Number of observations & 5,884 & 5,561 & 5,884 & 5,884 \\
\hline Log likelihood & $-1,781.14$ & $-1,780.90$ & $-1,599.50$ & $-1,599.50$ \\
\hline Wald Chi ${ }^{2}$ & $248.99^{* * *}$ & $248.53 * * *$ & $1,074.78^{* * *}$ & $1,074.67$ \\
\hline \multicolumn{5}{|c|}{ Dependent variable: Process Inovations $s_{t}$ (random effects probit regression) } \\
\hline Export Propensity $_{\mathrm{t}-1}$ & $0.15^{* *}(0.07)$ & $0.19 * * \quad(0.09)$ & $0.11 * \quad(0.06)$ & $\begin{array}{l}0.13^{*} \\
(0.07)\end{array}$ \\
\hline Numerical Flexibility $_{t-1}$ & $0.01 * * *(0.00)$ & $0.01 * * *(0.00)$ & $\begin{array}{l}0.00 \\
(0.00)\end{array}$ & $\begin{array}{l}0.00 \\
(0.00)\end{array}$ \\
\hline Export Prop.t-1 $_{{ }^{1}}$ X Num. Flex ${ }_{t \cdot-1}$ & & $\begin{array}{l}-0.00 \\
(0.00)\end{array}$ & & $\begin{array}{l}-0.00 \\
(0.00)\end{array}$ \\
\hline Process Innovations $t_{t-1}$ & & & $1.06 * * *(0.05)$ & $1.06 * * *(0.05)$ \\
\hline Controls as in Table $6^{\mathrm{a}}$ & Yes & Yes & Yes & Yes \\
\hline Sector Dummies & Yes & Yes & Yes & Yes \\
\hline Industry Dummies & Yes & Yes & Yes & Yes \\
\hline Number of observations & 5,884 & 5,884 & 5,884 & 5,884 \\
\hline Log likelihood & $-2,761.17$ & $-2,760.87$ & $-2,595.70$ & $-2,595.57$ \\
\hline Wald $\mathrm{Chi}^{2}$ & $288.48 * * *$ & $288.62 * * *$ & $912.32 * * *$ & $912.19 * * *$ \\
\hline
\end{tabular}

All regressions include a constant. The coefficients are marginal effects and represent the change in probability due to a one-standard deviation increase in the independent variable at the means of the other variables (or the change from 0 tol in the case of a dummy variable). Standard errors are reported in parentheses.

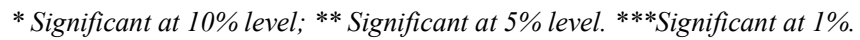

aThe control variables are the same as in Table 6: log of size, log of age, foreign shareholders, temporal workers, industry's technological intensity and labor productivity.

\section{Acknowledgements}

The preferred spelling of the word "acknowledgment" in America is without an "e" after the "g". Avoid the stilted expression, "One of us (R. B. G.) thanks ..." Instead, try "R. B. G. thanks". Put sponsor acknowledgments in the unnum-bered footnote on the first page.

\section{Nomenclature}

I. S. Jacobs and C. P. Bean, "Fine particles, thin films and exchange anisotropy," in Magnetism, vol. III, G. T. Rado and H. Suhl, Eds. New York: Academic, 1963, pp. 271-3Acknowledgements

\section{References}

[1] G. Eason, B. Noble, and I. N. Sneddon, "On certain integrals of Lipschitz-Hankel type involving products of Bessel functions," Phil. Trans. Roy. Soc. London, vol. A247, pp. 529-551, April 1955. (references)
[2] J. Clerk Maxwell, A Treatise on Electricity and Magnetism, 3rd ed., vol. 2. Oxford: Clarendon, 1892, pp.68-73.

[3] G. Eason, B. Noble, and I. N. Sneddon, "On certain integrals of Lipschitz-Hankel type involving products of Bessel functions," Phil. Trans. Roy. Soc. London, vol. A247, pp. 529-551, April 1955. (references)

[4] J. Clerk Maxwell, A Treatise on Electricity and Magnetism, 3rd ed., vol. 2. Oxford: Clarendon, 1892, pp.68-73.

[5] I. S. Jacobs and C. P. Bean, "Fine particles, thin films and exchange anisotropy," in Magnetism, vol. III, G. T. Rado and H. Suhl, Eds. New York: Academic, 1963, pp. 271-350.

[6] K. Elissa, "Title of paper if known," unpublished.

[7] R. Nicole, "Title of paper with only first word capitalized," J. Name Stand. Abbrev., in press.

[8] Y. Yorozu, M. Hirano, K. Oka, and Y. Tagawa, "Electron spectroscopy studies on magneto-optical media and plastic substrate interface," IEEE Transl. J. Magn. Japan, vol. 2, pp. 740-741, August 1987 [Digests 9th Annual Conf. Magnetics Japan, p. 301, 1982].

[9] M. Young, The Technical Writer's Handbook. Mill Valley, CA: University Science, 198. 